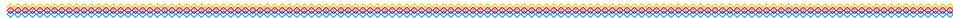

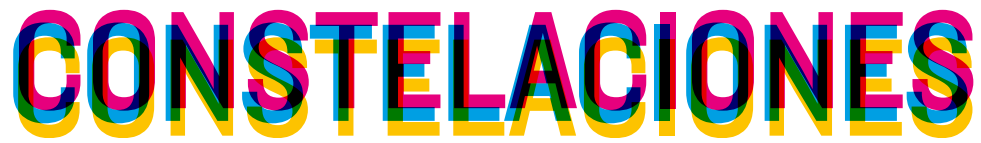

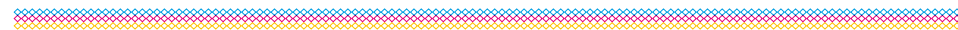




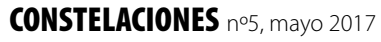

Revista de Arquitectura de la Universidad CEU San Pablo

Architecture Magazine of CEU San Pablo University

Periodicidad anual

Annual periodicity

COMITÉ DE REDACCIÓN EDITORIAL COMMITTEE

\section{Dirección Directors}

Juan García Millán

Santiago de Molina

Jefa de Redacción Editor in Chief

Covadonga Lorenzo Cueva

Secretario de Redacción Editorial Clerk

Rodrigo Núñez Carrasco

Maquetación y producción Design and production

María Fernández Hernández

Clara Martínez-Conde Rubio

Revisión de textos en inglés English Editing

Carlota Sáenz de Tejada Granados

Responsable Web Web Page Manager

María Isabel Castilla Heredia

Diseño Original Original Design

Juan Roldán Martín

\section{Vocales Board Members}

María Dolores Gómez Pulido. Escuela Politécnica Superior, Universidad CEU San Pablo, Madrid

Rocío Carvajal Alcaide. Escuela Politécnica Superior, Universidad CEU San Pablo, Madrid

Clara Eugenia Maestre Galindo. Escuela Politécnica Superior, Universidad CEU San Pablo, Madrid

\section{CONSEJO EDITORIAL EDITORIAL BOARD}

Beatriz Colomina. School of Architecture, Princeton University, New Jersey

Carmen Díez Medina. Escuela de Ingeniería y Arquitectura, Universidad de Zaragoza

María Antonia Frías Sargadoy. Escuela Técnica Superior de Arquitectura, Universidad de Navarra

Juan Miguel Hernández Léon. Escuela Técnica Superior de Arquitectura, Universidad Politécnica de Madrid

Juan José Lahuerta Alsina. Escuela Técnica Superior de Arquitectura, Universidad Politécnica de Cataluña, Barcelona

Eduardo Leira Sánchez. Ex director del Plan General de Ordenación Urbana, Madrid

Joaquín Medina Wamburg. Facultad de Aquitectura Diseño y Urbanismo, Universidad de Buenos Aires

Zaida Muxí Martínez. Escuela Técnica Superior de Arquitectura, Universidad Politécnica de Cataluña, Barcelona José Joaquín Parra Bañón. Escuela Técnica Superior de Arquitectura, Universidad de Sevilla

Víctor Pérez Escolano. Escuela Técnica Superior de Arquitectura, Universidad de Sevilla

Fernando Pérez Oyarzún. Escuela de Arquitectura y Diseño, Pontificia Universidad Católica, Santiago de Chile Judith Sheine. School of Architecture and Allied Arts, University of Oregon, Portland

Andrés Walliser Martínez. Global Design, New York University, Nueva York

\section{ISSN 2340-177X}

Depósito legal M-13872-2013

(c) de los textos, sus autores

(c) de las imágenes autorizadas

(C) Revista Constelaciones

๑) Escuela Politécnica Superior, Universidad CEU San Pablo

Universidad CEU San Pablo

Escuela Politécnica Superior

Urbanización Montepríncipe, s/n

Alcorcón, 28925. Madrid (España)

constelaciones@eps.ceu.es

www.uspceu.es

www.revistaconstelaciones.wordpress.com

Edición Edition

Fundación Universitaria San Pablo CEU

Madrid, España

Impresión Printing

VA Impresores

Impreso en España Printed in Spain

Distribución Distribution

CEU Ediciones

\author{
INDEXACIÓN INDEXING \\ Índices Index \\ Latindex \\ Avery Index \\ ErihPlus \\ MIAR
}

Bases de datos Data bases

Dialnet

Índices en evaluación Evaluation Index

Web of Science

Scopus

Dulcinea

EBSCO

Sherpa Romeo
Los textos que componen Constelaciones se obtienen mediante convocatoria pública. Para que los trabajos recibidos entren en el proceso de selección de los artículos a publicar deben ser trabajos originales no publicados anteriormene, con una extensión recomendada de 3.000 palabras, título, resumen (un máximo de 150 palabras) y palabras clave (un mínimo de cuatro palabras), en español y en inglés. Tras haber cumplido estos requisitos (y los correspondientes incluidos en las normas editoriales de la revista, disponibles para consulta en formato digital desde el comienzo de la convocatoria), tiene lugar un proceso de revisión y evaluación de los artículos previa aceptación de los mismos para su publicación. Para acometer dicho proceso, y con el fin de asegurar la calidad de los contenidos, la revista Constelaciones recurre a evaluadores externos a la institución editora y anónimos (cada artículo es evaluado por dos de ellos) encargados de someter a crítica los mismos. Todos los artículos de investigación publicados en esta revista han pasado por dicho proceso. La recepción de artículos se extendió hasta el 30 de septiembre de 2016. Texts included in Constelaciones are obtained by public announcement. Only original papers that have not been previously published will be included in the process of selection of articles. They should not exceed 3.000 words and should include a title, an abstract (no more than 150 words) and keywords (a minimum of four words), in Spanish and English. After having fulfilled these requirements (and those included in magazine editorial standards, available for consultation from the beginning of the Call for Papers), occurs a process of review and evaluation of articles upon acceptance of them for publication. To undertake this process, and in order to ensure the quality of the contents, Constelaciones turns to external and anonymous evaluators to the institution (each article is evaluated by two of them) responsible for the critic. All the articles published in this journal have undergone this process. The deadline for reception was extended until September 30, 2015.

Todos los derechos reservados. Esta publicación no puede ser reproducida, ni en todo ni en parte, ni registrada, ni transmitida, ni almacenada en ninguna forma ni por ningún medio, sin la autorización previa y por escrito del equipo editorial. En este número se han utilizado algunas imágenes de las que no se ha podido identificar al propietario de los derechos. En estos casos hemos entendido que las imágenes son de libre uso. En caso de identificar alguna de estas imágenes como propia, por favor, póngase en contacto con la redacción de Constelaciones. Los criterios expuestos en los diversos artículos de la revista son responsabilidad exclusiva de sus autores y no reflejan necesariamente los que pueda tener el equipo editoral. El equipo editorial de la revista no se responsabiliza de devolver la información enviada a la redacción a no ser que se le solicite expresamente. All rights reserved. This publication cannot be reproduced, in whole or in part, nor registered, transmitted or stored in any form or by any means, without the written permission of the Editorial team. In this issue some images were used without knowing the owner of the rights. In these cases, we have understood that the images are free of use. In case you identify written permission of the Editorial team. In this issue some images were used without knowing the owner of the rights. In these cases, we have understood that the images are free of use. In case you identify
any of these images as your own, please, contact with the Editorial staff of Constelaciones. The opinions expressed in this issues's articles are entirely the responsibility of their authors and are not necessarily shared by the editors of this journal. The publisher don't take responsibility for returning submitted material which is not expressly requested. 

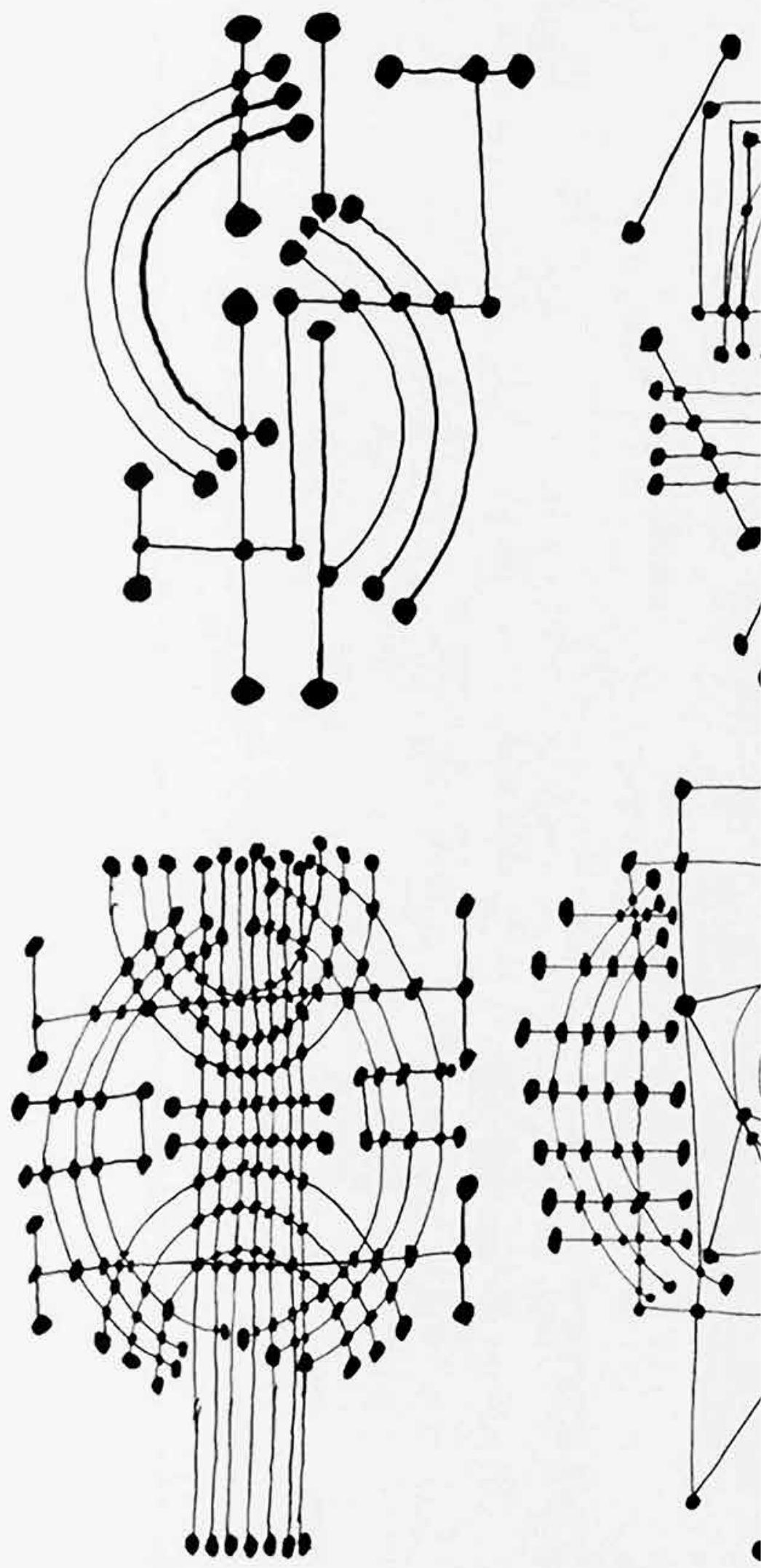


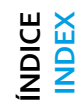

จ

ก)

品

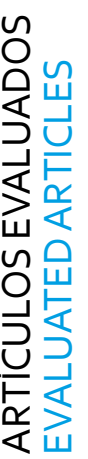

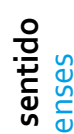

बํำ

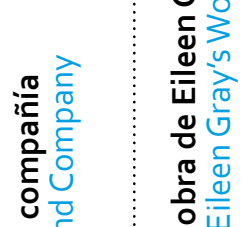

드.

ฮั

茄

:

ที่ ปั อ

苦云

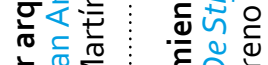

过

ह $\frac{2}{3}$

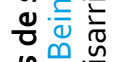

눈

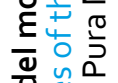

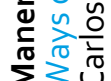

นับ

음

๗ั

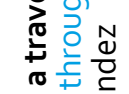

号

궁워

뜬

원

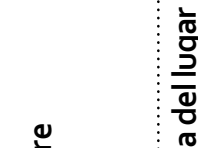

임

ส

응

离

$: \frac{\mathscr{2}}{ \pm}$

을

tั

ग

ํํำ

ํㅡㄹ

:

응 $\frac{\cup}{0}$

บับ

인

든

冚

号京

ब

ฮั

을

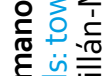

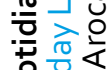

언

으 $\frac{\pi}{\pi}$

产

등 똥

告崖

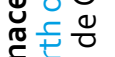

ํํㄴ

일

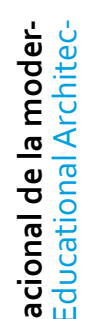

高
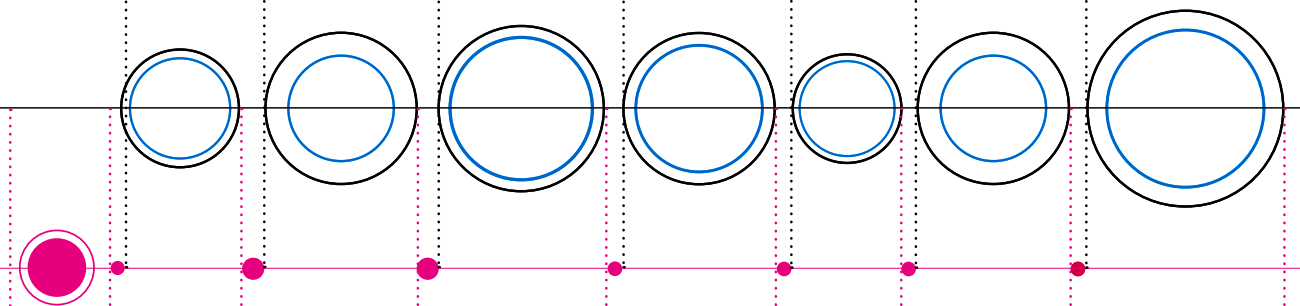

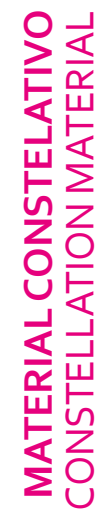

岂㟧

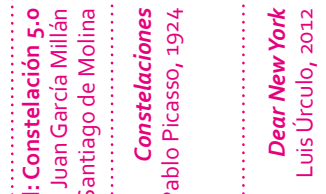

$=\quad \stackrel{m}{\sim}$

$\stackrel{\bullet}{v}$
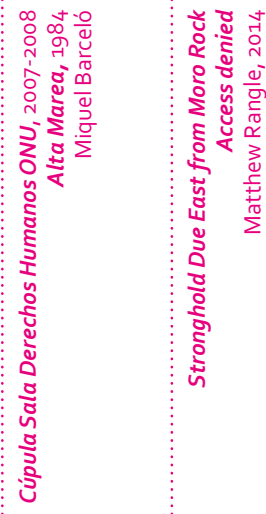

$\overline{6}: \AA$

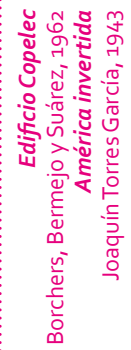

$\infty$

응 


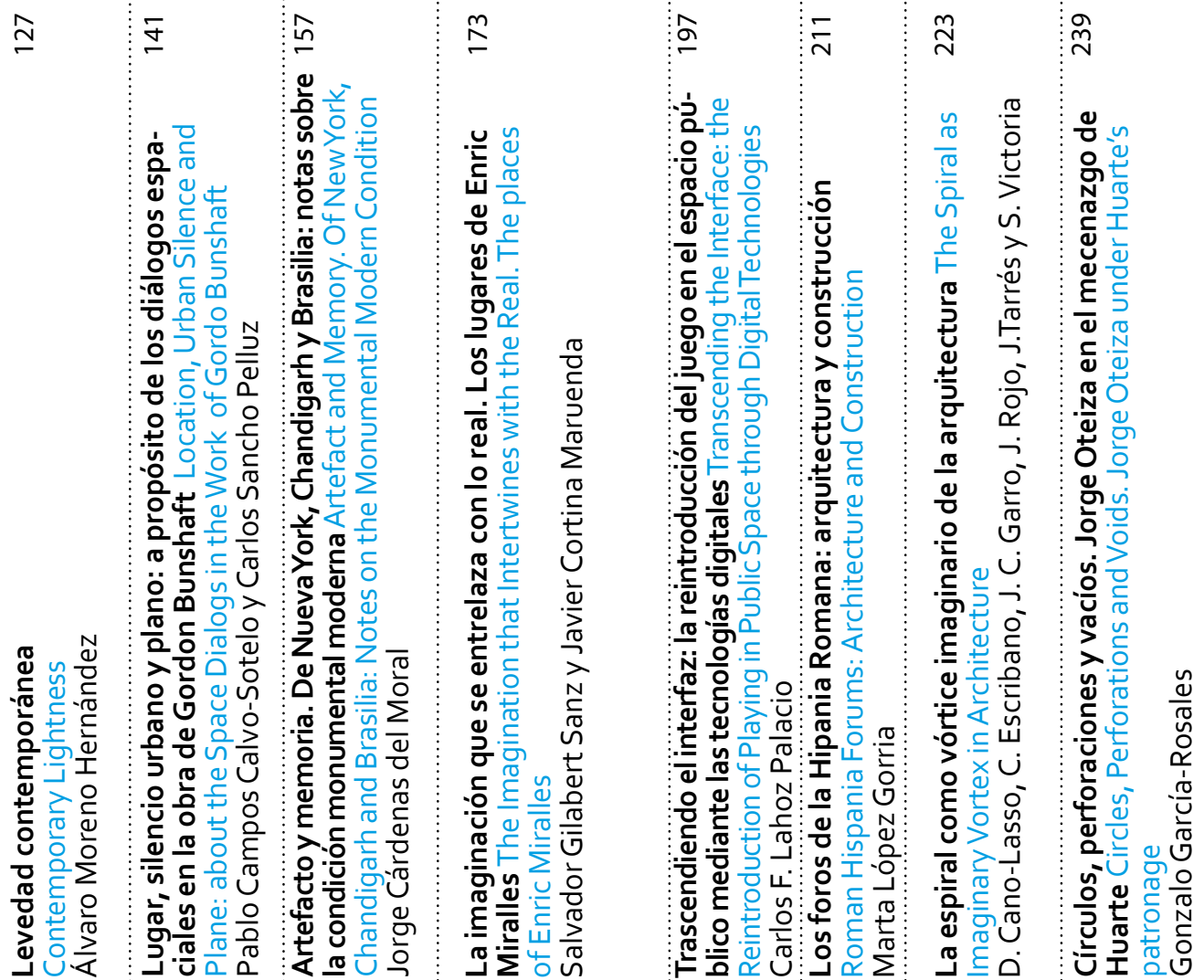
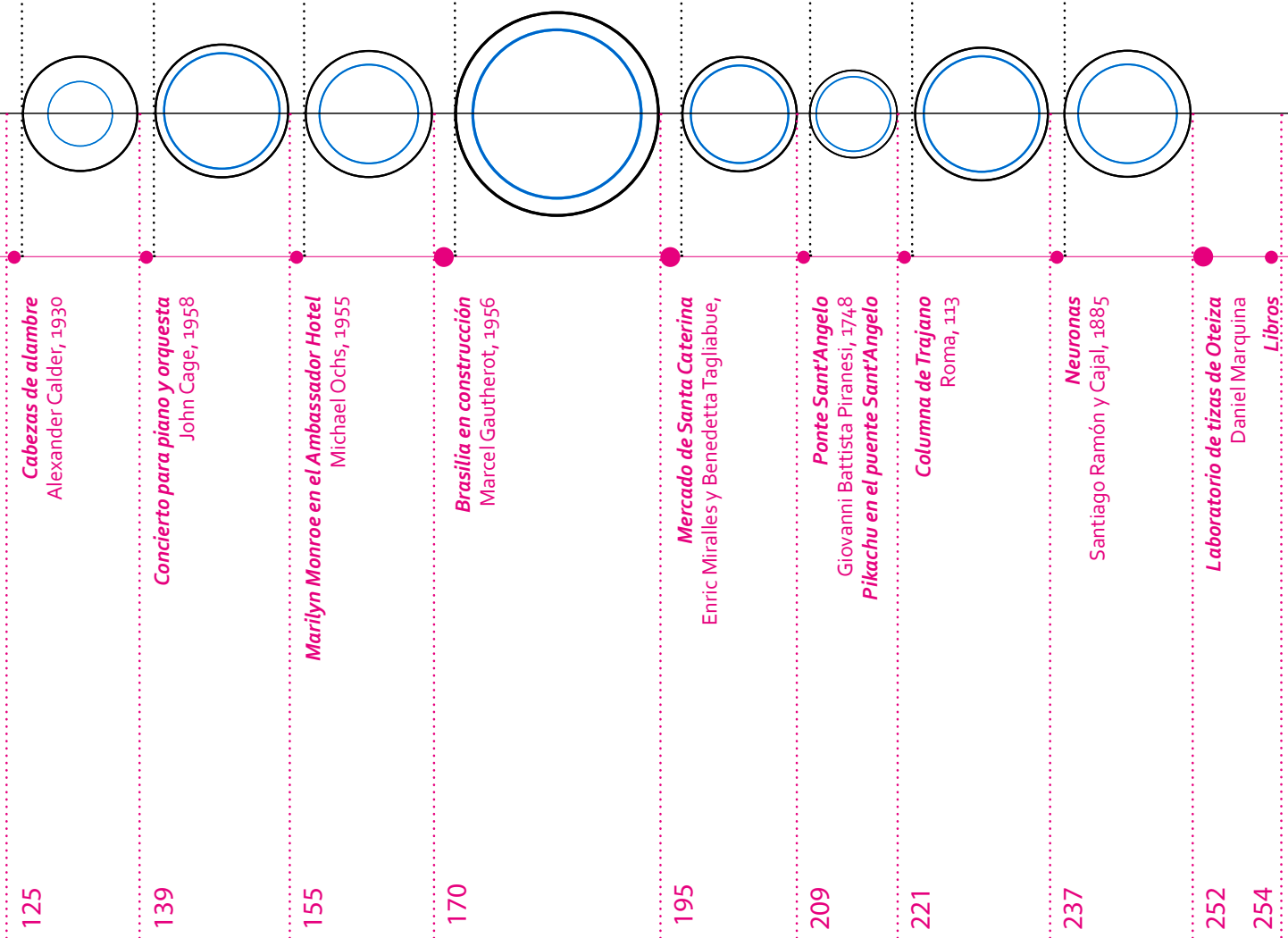


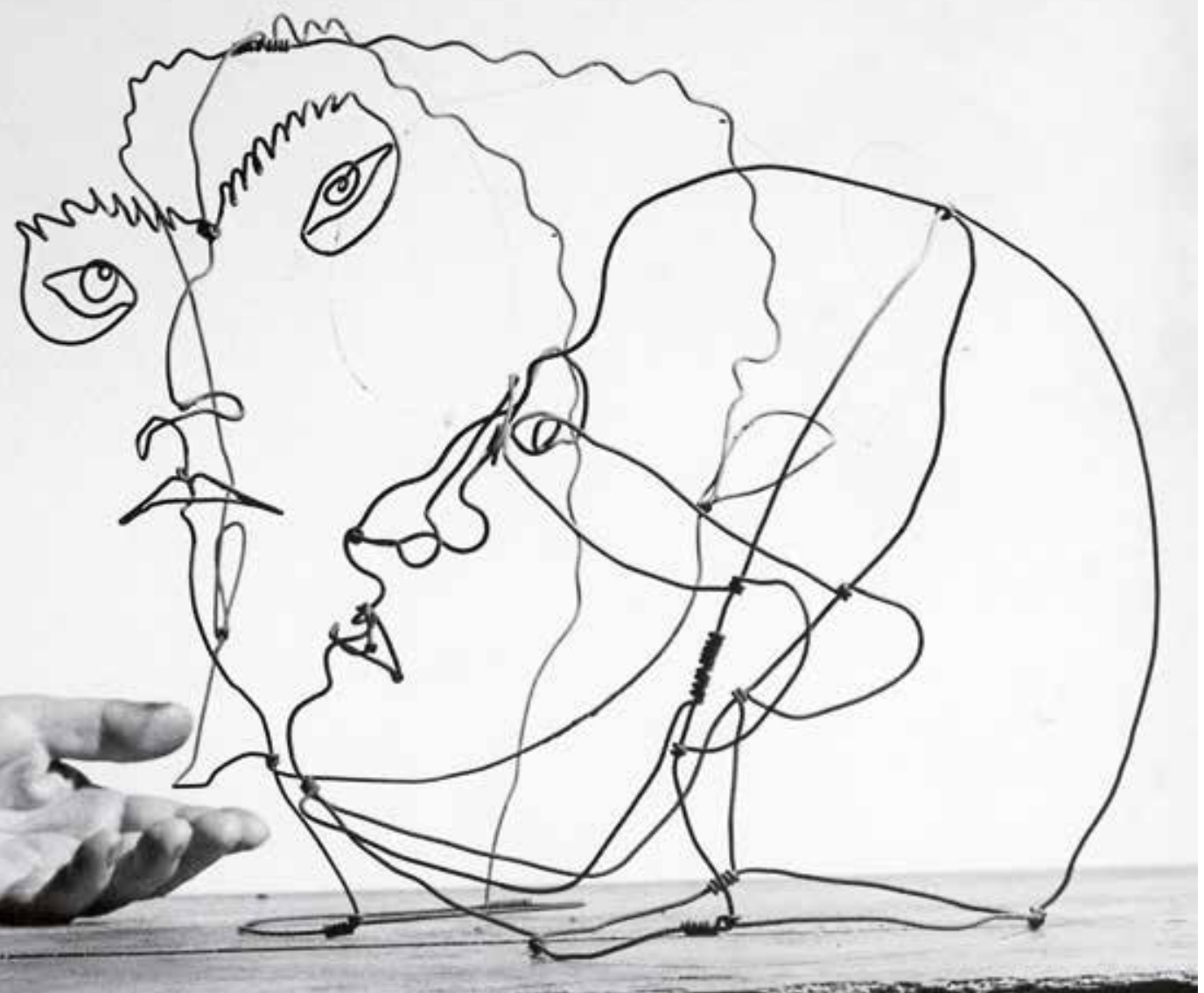




\title{
Levedad contemporánea
} Contemporary Lightness

\author{
Álvaro Moreno Hernández \\ Escuela Técnica Superior de Arquitectura, Universidad Politécnica, Madrid \\ Traducción Translation Álvaro Moreno Hernández, Mar Callejón Gutiérrez
}

\section{Palabras clave Keywords}

Transparencia, ligero, estable, Duchamp, Souto de Moura, Nouvel.

Transparency, light, stable, Duchamp, Souto de Moura, Nouvel.

\section{Resumen}

¿Es posible hablar de una levedad propia de la arquitectura contemporánea? Y si es así, ¿cómo caracterizarla? Tomando como referencia la exposición Light Construction celebrada en el MoMA en 1995, se analiza la propuesta teórica de su comisario expresada en el artículo principal de la exposición, su manifiesto. La mención que en él se hace de Duchamp permitirá iniciar una reflexión sobre el sentido de la arquitectura como obra de arte que dará forma al concepto propuesto: levedad. Comparar dos actuaciones sencillas como la instalación Windows en Venecia por Souto de Moura y la adecuación de un hotel realizada por Nouvel en Lucerna ayuda a mostrar la idea de levedad propuesta.

\section{Abstract}

Is it possible to speak about a lightness typical of contemporary architecture? And if this is so, how to characterize it? Taking as reference the exhibition Light Construction, which was held in 1995 at the MoMA, the theoretical proposal of its curator, expressed in the main article of the exhibition, its manifesto, is analysed. The reference to Duchamp appearing on it will help to start a reflection on the sense of architecture as a work of art that will shape the proposed concept of lightness. Comparing two simple actions such as Windows, an installation in Venice by Souto de Moura and the hotel adaptation by Nouvel in Lucerna helps to show the proposed idea of lightness. 
Cuando Italo Calvino se ocupaba de la levedad como uno de sus temas preferidos, tan significativo como para ser transmitido en sus propuestas para un nuevo milenio, no definía estrictamente lo que entendía por levedad, sino que se aproximaba mediante fragmentos literarios escogidos para desvelar el carácter que tenía para él. Su cometido era doble: por un lado, ofrecía al lector -ya que la muerte repentina le impidió impartir sus conferencias- su imaginario personal en relación con la levedad y por otro, al emplear la escena del jinete errante encaramado a un cubo volador con la que ilustraba el final de su ponencia, le regalaba, a su juicio, la imagen más capaz y adecuada para portar ese concepto de levedad al próximo (ya actual) milenio. (1)

La tarea de este escrito es análoga. En este caso, se ofrece una frase, un enunciado que condensa la tesis del artículo: la levedad se manifiesta en la arquitectura contemporánea como oscilación de lo estable. Y por medio de tres aproximaciones, tres reflexiones en torno a una exposición, al concepto de obra de arte y a una pareja de obras construidas, se caracteriza el sentido de esta forma de levedad en el contexto de la arquitectura de final del siglo xx. La proposición inicial, un tanto enigmática, se pretende que funcione como un reactivo; puesta en relación con determinadas obras o elementos haría patente una levedad propia de lo contemporáneo y diferente de interpretaciones anteriores.

En la arquitectura clásica, vertical, la levedad se reconocía asociada al esfuerzo y la maestría en dominar al peso por medio de la geometría y la luz, como arte en el que la materia se vence a sí misma. A la modernidad, que liberaba el plano del suelo de los pesados muros y su transmisión de cargas, le correspondía una levedad clara y distinta que se interpretaba como ligereza y se confiaba a la tríada de materiales modernos: hormigón, acero y vidrio, especialmente a éste último por sus cualidades de transparencia y reflejo. La levedad contemporánea incorpora ambas lecciones, dando un paso más allá al superar la condición objetual de la arquitectura e incluir de forma determinante la relación con el usuario que la experimenta. No es casual que, en

When Italo Calvino dealt with lightness as one of his favorite subjects -and so significant to be included in his memos for the next millennium- he did not define lightness in a restricted way, but revealed that nature of lightness in which he was concerned by literary passages previously selected. There was a double goal in it; on the one hand, he offered readers -because he died suddenly before lecturing- his personal references relating to lightness and on the other hand, he gave them the most able and appropriate image to hold on that concept of lightness to the next (now current) millennium by using the scene of the wandering rider perched on a flying bucket. (1)

The task of this paper is quite similar. An idea is suggested, a sentence that summarizes the thesis of this paper: lightness is shown in contemporary architecture as the oscillation of the stable. And through three approaches, three reflections revolving around an exhibition, the concept of work of art and a pair of architectural works, it is possible to characterize the meaning of this kind of lightness inside the architectural context at the end of the 20th century. The initial proposal, rather enigmatic, is expected to operate as a reagent: close to certain works or elements, it would help to show a typical contemporary lightness, different than previous approaches.

If classic architecture, that rises vertically, expresses lightness by the effort and mastery in managing the weight through geometry and light, as an art in which matter overtakes itself. If modernity that releases the ground plane from heavy walls and its loads, shows a clear and a distinctive lightness interpreted as lightweight and relied upon the triad of modern materials -concrete, steel and glass- and particularly the last one because of its qualities of transparency and reflect. 
este sentido, Duchamp junto a su obra, surja como referencia para entender esta forma de levedad.

Construyendo la levedad: Light Construction. En los últimos quince años del siglo, la levedad se ha convertido fugazmente en un tema que centra la atención, tanto de la propia disciplina como de campos afines a ella. El año 1985 marca un hito, con la celebración de la manifestación Les Immatériaux en el CNAC Georges Pompidou de París y la preparación de las conferencias de Calvino, la primera de ellas dedicadas a la levedad. Pero será diez años después, en la década de los noventa, cuando tres eventos estrictamente arquitectónicos se fijen sobre la levedad desde puntos de vista complementarios.

En el año 1994, la corporación ANY edita el número de 5 de su revista ANYmagazine titulado Lightness y en el año 1995, también en Nueva York, se desarrollan paralelamente el seminario The Culture of Glass, en la Universidad de Columbia y la exposición Light Construction, en el MoMA (entre septiembre de 1995 y enero de 1996). (2) Sin duda, el más mediático de todos ellos fue este último, por la entidad de la institución organizadora. (3)

La exposición, que mostraba treinta y tres obras de diferente procedencia, hacía de la transparencia y la ligereza sus señas de identidad. El director del museo, Glenn D. Lowry, en el prólogo del catálogo de la exposición no podía evitar la comparación como exhibición de referencia entre ésta, que cerraba el siglo hablando de una nueva sensibilidad en arquitectura y la primera Exposición Internacional dedicada a la Arquitectura Moderna en el mismo museo, que originó The International Style en 1932. Dejando aparte esa polémica, que en alguna medida influyó en la crítica de la exposición, interesa centrar la atención en el artículo principal que encabeza el catálogo y que equivaldría a su manifiesto. (4) En él, el comisario Terence Riley fija la posición teórica que le permite reunir la disparidad de proyectos y obras recogidos en la muestra. Constata el desplazamiento del interés en la arquitectura desde los problemas formales a la naturaleza

Contemporary lightness assimilates both approaches to take a step forward, overtaking the nature of architecture just as object and including in a decisive way, the relationship between architecture and people who experience it. It is not coincidence that, in this sense, Duchamp and his work, appear as reference to understand this kind of lightness.

Constructing Lightness: Light Construction. During the last fifteen years of the 20th century, lightness briefly became a central subject both for architectonic discipline and fields related to it. 1985 was a landmark year due to the exhibition Les Immatériaux, at CNAC Georges Pompidou in Paris, and the writing of Calvino's lectures, the first of them devoted to lightness. But it will be ten years later, in the mid-nineties, when three exclusively architectonic events will put the focus on lightness from complementary points of view.

In 1994, the number five of its periodical ANYmagazine, entitled Lightness, was published by ANY Corporation and in 1995, also in New York, took place at the same time a seminar at Columbia University, The Culture of Glass, and an exhibition at MoMA, Light Construction (September 1995 to January 1996). (2) Undoubtedly, this last event had the largest media impact due to the importance of MoMA as organizing entity. (3)

The exhibition showed 33 works from different approaches, with transparency and lightweight as its distinguishing features. In the preface of the exhibition's catalogue, Glenn D.Lowry, MoMA Director, could not avoid the comparison as landmark exhibition between this one -that closes the century dealing with a new sensibility in architecture- and the first Inter- 
y el potencial de las superficies y reconoce la influencia de la técnica de los medios electrónicos y los ordenadores en la investigación de artistas y arquitectos, al replantear las relaciones entre arquitectura, percepción visual y estructura.

De modo que, aun cuando la transparencia y la ligereza eran lo distintivo de estas obras, el acercamiento era muy diferente al que tuvo la primera modernidad. Si aquel entendimiento de la levedad se correspondía inequívocamente con ellas por el uso del vidrio, las obras expuestas exhibían un repertorio diferente de materiales -ya fueran trenzados, perforados o translúcidos- que filtraban el paso de la luz y fundamentalmente, de la visión, lo que establecía una distancia entre la obra y el espectador.

Para argumentar la idea de la exposición y justificar la selección mostrada, en el artículo se analizaban las obras bajo diferentes miradas que iban desde la física, al desarrollo tecnológico y su influencia, tanto en la creación y desarrollo del proyecto como en la eficiencia y ecología de las soluciones constructivas. Sin embargo, pienso que es al tratar el tema de la transparencia desde los campos del arte y la arquitectura cuando se origina una falla por la que se filtra un sentido propio de la levedad contemporánea, que se distingue de lo expresado por el comisario en ese texto. Riley se apoya en el conocido artículo de Colin Rowe y Robert Slutzky Transparency: Literal and Fenomenal, Part I, aparecido en 1964 en la revista Perspecta, (5) para contrastar la complejidad y la ambigüedad de obras contemporáneas de arquitectura, con la sencillez de esos dos tipos de transparencia moderna: la literal y la fenomenal. (6)

La obstrucción a la transparencia como característica de la arquitectura de ese momento es relevante y se convierte en una idea que permite revisar el artículo principal de Light Construction desde otro supuesto. Para clarificar el planteamiento, ya que en el artículo de la exposición no se hace explícitamente así, esta obstrucción se podría interpretar, a su vez, como literal o fenomenal. (7) La forma literal de obstruir la transparencia es la del empleo de los materiales mencionados anteriormente. Su uso crea espacios muy di-

national Exhibition devoted to Modern Architecture at MoMA, that led to The International Style in 1932. Leaving this controversy aside -even though in some way the critic of this exhibition was influenced by it- it is better to focus on the main article that head the catalogue and could be considered as its manifesto. (4) In that manifesto, the curator Terence Riley sets the theoretical position that lets him collect the disparity of projects and works shown in the exhibition. He confirms the shift of architectural interest from formal problems to the nature and potential of surfaces, and also recognizes the influence of electronic media and computers on the research developed by artists and architects when they reconsider the connections amongst architecture, visual perception and structure.

So that, although transparency and lightness were the distinctive character of those works, their approach was very different from that of the first modernity. If that understanding of lightness clearly corresponded to architectural works by the use of glass, the displayed works exhibited a collection of very different materials -plaited, holed or translucent- that filtered light and, essentially vision, establishing a distance between work and spectator.

In order to argue for the exhibition idea and justify the collected works displayed, these are analyzed under different aspects, from physics to technological development and its influence in both, creation and project development and efficiency and ecology in building solutions. But I think that when the curator talks about transparency from the fields of art and architecture, a fault arises that lets a distinctive meaning for contemporary lightness appear, a different meaning from that shown in the article. Riley relies on the well-known article by Colin Rowe and Robert Slutzky Transparency: Literal and Phenomenal, Part I, 
ferentes al ideal moderno del Palacio de Cristal, en el que la proporción de vidrio y acero permite un espacio brillante y luminoso, sin sombras. (8) Es una aplicación directa del material por sus características propias.

La obstrucción fenomenal no depende directamente del material sino de las relaciones que se establecen en la obra y afecta a la comprensión. Riley habla de ella en su artículo en dos momentos: refiriéndose a una obra de arte y a un proyecto.

El proyecto elegido es el que Rem Koolhaas realizó para el concurso de la Biblioteca de Francia (Fig. 1) y para referirse a él, utiliza las palabras de Anthony Vidler: "Como un objeto sólido, no como un vacío, con los volúmenes interiores excavados de un bloque cristalino como si flotaran dentro de él, en suspensión amébica. Estos volúmenes son representados en la superficie del cubo como una presencia umbría, con una tridimensionalidad ambigua y plana, superponiéndose los unos con los otros en un juego de densidades amorfas [...] El sujeto queda suspendido en un momento crítico entre el conocimiento y la obstrucción". (9) Esta ambigüedad, para la que Riley no encuentra acomodo en las transparencias modernas de Rowe y Slutzky y que termina emparentando con el Gran Vidrio de Duchamp, remite al tratamiento de lo informe y la desorientación. Estos mecanismos provocan una resistencia a la comprensión del objeto, evitando quedar encasillado en lenguajes establecidos.

Volviendo al texto de Vidler en relación a las fachadas, tiene mucho que ver con la apreciación de György Kepes cuando apunta en Language of Vision (10) el nuevo significado de una transparencia que evalúa la profundidad de un objeto por su densidad óptica. Por tanto, esta operación de obstrucción, que es de raíz fenomenal porque afecta a la comprensión, incrementa su impacto gracias a mecanismos literales asociados a la densidad.

En cuanto a la obra de arte que sirve de apoyo al discurso del comisario, ésta no podía ser otra que Gran Vidrio de Marcel Duchamp. (Fig. 2) Del

published in 1964 in Perspecta magazine (5) to contrast complexity and ambiguity in contemporary architecture with the simplicity of those two kinds of modern transparency: literal and phenomenal. (6)

Obstruction to transparency as a quality in the architecture of that period is relevant and turns into an idea that allows a revision of the main article of Light Construction from another point of view. To clarify the proposal -since the article did not explicitly do it- this obstruction could be also interpreted, in turn, as literal or phenomenal. (7) The literal way to obstruct transparency can be achieved by dealing with the above-mentioned materials. The use of these materials creates spaces very different from the modern ideal of Crystal Palace, in which the proportion of glass and steel allows a bright and luminous space, without shadows. (8) This is the direct employment of material by its own properties.

Phenomenal obstruction does not depend directly on the material itself, but on the relations that are established on site concerning the understanding.

Riley alludes to it twice in his article: talking about a work of art and talking about an architectural project. The selected project is the France Library competition project by Rem Koolhaas (Fig. 1) and, when referring to it, he uses Anthony Vidler's words: "As a solid, not as a void, with the interior volumes carved out of a crystalline block so as to float within it, in amoebic suspension. These are then represented on the surface of the cube as shadowy presences, their threedimensionality displayed ambiguously and flattened, superimposed on one another in a play of amorphous densities [...] 

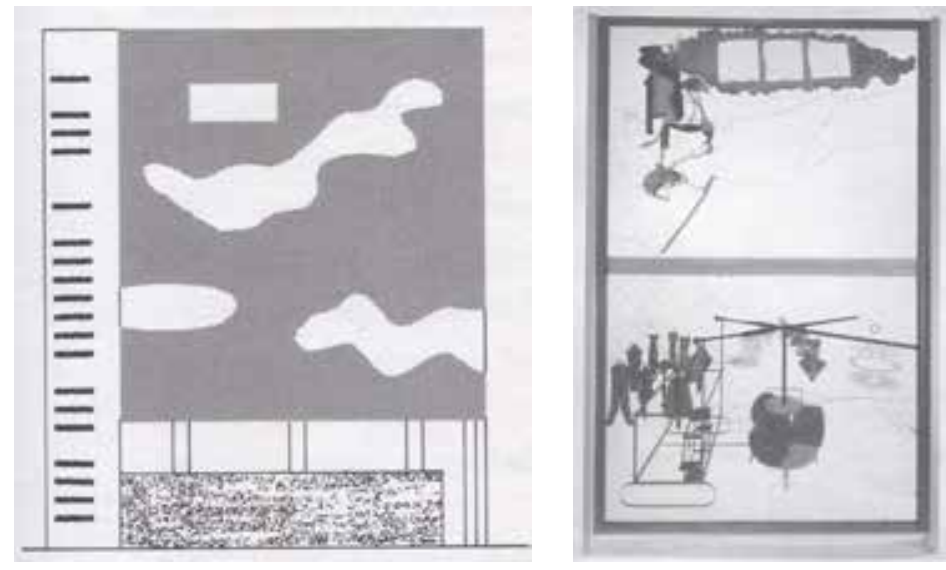

Fig. 1. Koolhaas, Rem -O.M.A.: Proyecto de concurso para la Biblioteca Nacional de Francia en París. 1989. Fachada al Périphérique. En el catálogo de la exposición Light Construction, p.15.

Fig. 2. Duchamp, Marcel. Gran Vidrio. 19151923. En el catálogo de la exposición Light Construction, p. 14.

artículo se deduce que la demora que Octavio Paz adivina en esta obra es interpretada por Riley de dos maneras: en términos de espacio, como una interposición y en términos de tiempo, como un retardo.

Tomando el edificio de oficinas ACOM de van Berkel como edificio representativo, (Fig. 3) Riley lo analiza en estos términos: el nuevo cerramiento de materiales translúcidos y paneles de lamas orientables oculta el edificio original, entorpeciendo la visión y creando un espacio físico entre ambos cerramientos, actuando como un filtro, algo interpuesto entre el observador y el interior del objeto. El empleo de esos materiales provoca también una detención de la luz, que queda atrapada en el reflejo al atravesarlos. (11) En mi opinión, la interpretación que hace en él sobre la demora es excesivamente literal, física, puesto que lo que queda atrapado en ella es nuestra comprensión. Basta comparar las imágenes de ambas obras para constatarlo.

Octavio Paz identifica la demora o el retraso con la posibilidad de análisis. (12) Es decir, el tiempo necesario para comprender la obra, o tratar de ha-

The subject is suspended in a difficult moment between knowledge and blockage". (9) This kind of ambiguity, which Riley could not identify with Rowe and Slutzky's modern transparency, and that he finally links to Large Glass by Duchamp, refers to the treatment of shapeless and confusion. These two processes lead to a resistance to object understanding, avoiding to be categorized in common languages.

Returning to Vidler's text about the facades on this project, it has a lot to do with György Kepes when he points out in Language of Vision (10) the new meaning of transparency, that evaluates the depth of an object by its optical density. Therefore, this blockage operation, that is phenomenal in its origin because it affects comprehension, increases his impact thanks to literal mechanisms associated with density.

Regarding the work of art that supports the curator's thesis in the article, this could not be other than the Large Glass by Marcel Duchamp. (Fig. 2) As may be seen from the article, Riley figures out the delay that Octavio Paz guesses for this work in two ways: in terms of space, as interposition, and in terms of time, as lag.

Considering ACOM Office Building by Van Berkel as representative work in the exhibition (Fig. 3), Riley analyzes it in the following terms: the new enclosure made up of translucent materials and adjustable slats panels hide the original building, interfering vision and creating a physical space between both building envelopes. In this way, it acts as a filter, something interposed between observer and object's interior. The use of those materials also caused a light stopping, 
cerlo, es un tiempo 'regalado', 'expandido' que el observador emplea para tomar conciencia de la obra.

Posiblemente, Gran Vidrio sea la obra moderna más inquietante que se haya producido. En ella está todo a la vista: el soporte es vidrio, se puede rodear, se puede mirar desde todos los ángulos deseables, a la distancia que se considere; existen notas manuscritas, fotografías en blanco y negro compiladas por el autor en la Caja Verde; ha sido interpretado por críticos, escritores y filósofos; no hay nada escondido salvo el significado. La obstrucción no es material sino conceptual. Todo el material está a la vista, aunque como fragmentos sin orden aparente. Se muestran en el proceso, se requiere del observador para completar el sentido.

Este tipo de obstrucción está relacionada con la obra de arte y su explicación va más allá de la literalidad en la asignación de capas como objetos interpuestos o en la anécdota de las nubes como equivalencia formal entre la fachada de la biblioteca y el Gran Vidrio. Así, esta idea de levedad que se construye como obstrucción -en principio a la transparencia- sólo se entiende superando esquemas compositivos, si se recompone su sentido en la experiencia del observador.

Levedad, oscilación y estabilidad. Gianni Vattimo, en El arte de la oscilación (13) interpreta la existencia de la obra de arte en la sociedad actual desarrollando la analogía entre el choque (stoss), que Heidegger define como el efecto que se produce en el observador de la obra de arte y el shock, que Benjamin asigna al cine como un proyectil lanzado al espectador, a cada una de sus certidumbres, expectativas de sentido o hábitos de percepción. Es en el reconocimiento de la obra de arte, considerada no como un objeto que responde a un canon -en un mundo en el que ya no existe un canon- sino como aquel que pone en duda las propias certezas, donde puede estar la característica distintiva de la existencia en nuestra época, tal como recordaba Solà-Morales en su Arquitectura débil. (14)
Fig. 3. Suzuki, Hisao: ACOM Office Building de Van Berkel \& Bos. 1993. Catálogo de la exposición Light Construction, p. 66.

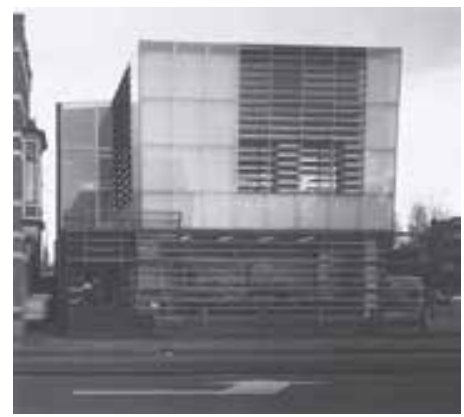

that remains trapped reflected on the materials when passing through them. (11) In my opinion, Riley's interpretation of Duchamp's delay in the ACOM Building is excessively literal, physical, because what remains captured in Duchamp's work is our understanding. It is enough to compare some pictures of both works to verify this.

Octavio Paz identifies delay or lag with the opportunity of analyzing. (12) That is to say, the needed time to understand this work, or trying to do it. It is a time 'given like a present', 'extended', that the observer spends to become aware of it.

Maybe, Large Glass was the most disturbing modern work ever produced. It shows everything: glass as material support, you can walk around, you can watch it from every desired point of view, no matter the distance; there are handwritten notes, black and white pictures left by the author in the Green Box; the work has been analyzed by critics, writers and philosophers; there is nothing hidden but the meaning. Obstruction is not material but conceptual. All material is exposed, although as fragments without an obviously order. These fragments are shown in the process; the observer is required to complete the meaning.

This type of obstruction is related to the work of art and its meaning goes beyond the literalism of assigning layers as interposed objects or the story of clouds, as formal equivalence between Koolhaas' Library and Large Glass. So, this idea of lightness built as obstruction - firstly to transparency- can only be understood by overtaking compositional thinking, if the meaning of the work is recomposed by the observer's experience. 

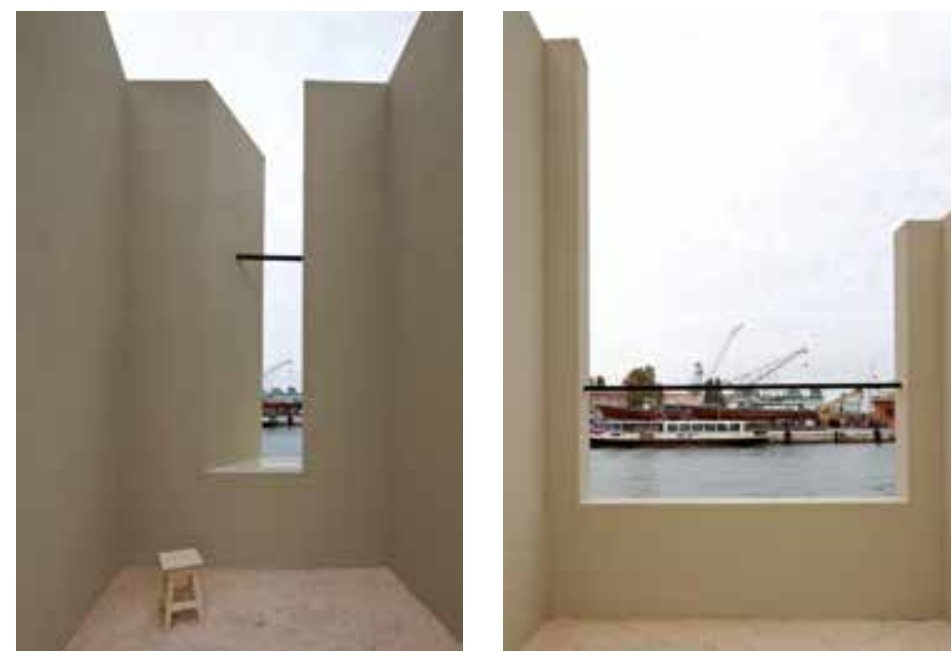

Gianni Vattimo lo comenta, explicando a Heidegger, cuando dice que la obra de arte no es un objeto que se pueda colocar en el mundo junto a los otros objetos, sino que ofrece "[...] una perspectiva general del mundo que entra en diálogo con nuestra perspectiva y que nos obliga a modificarla o, por lo menos, a profundizarla". (15) Este diálogo supone la puesta en duda de nuestro mundo. (16) La obra provoca un replanteamiento de nuestra perspectiva. Por un lado, abre nuestro conocimiento o nuestra experiencia, lo amplía, mientras que por otro, revela la pieza que no encaja o que no teníamos en cuenta, mueve el suelo bajo los pies al presentar un campo aún más extenso o desconocido. Es una situación que incomoda. Lo peculiar de este movimiento interno, emocional e intelectual es que no se detiene, o tiende a no hacerlo. Es a lo que Vattimo denomina oscilación y cualitativamente se asemeja al grado de obstrucción relacionado con la obra de arte con el que se concluía el anterior apartado.
Figs. 4-5. Saieh, Nicolás: Windows, Eduardo Souto de Moura. Venecia. 2012.

Lightness, Oscillation and Stability. Gianni Vattimo, in Art and Oscillation, (13) interprets the existence of the work of art in contemporary society developing the analogy between the crash (stoss) -that Heidegger defined as the effect that the work of art produces on the observer- and the shock, that Benjamin identified with the cinema as a bullet thrown to the audience, to every conviction, meaning expectation or perception habits. The recognition of the work of art could be considered the distinctive quality of existence in our time, as Solà-Morales reminds us in Arquitectura débil. (14) A work of art that does not follow a canon -in a world where canon does not exist anymore- puts into question our own convictions.

Gianni Vattimo, explaining Heidegger's philosophy, comments on this idea when he says that a work of art is not an object that you can set in the world amongst other objects, rather the work of art offers "[...] a general perspective of the world that causes a dialogue with our own perspective and this forces us to modify it or, at least, to take a close look at it". (15) This dialogue questions our world. (16) The work causes a reconsideration of our point of view. On the one hand, this dialogue opens our knowledge or our experience, it widens both; on the other hand, the same dialogue reveals the piece that is not fitting or the piece that we did not take in account, it shakes the ground under our feet showing a wider or an unknown field. It is a very disturbing state. What is characteristic of this kind of movement, inner, emotional and intellectual, is that it does not stop, or it tends not to do so. This is what Vattimo names oscillation and qualitatively, it resembles the obstruction degree related to the work of art that closed the last section. 

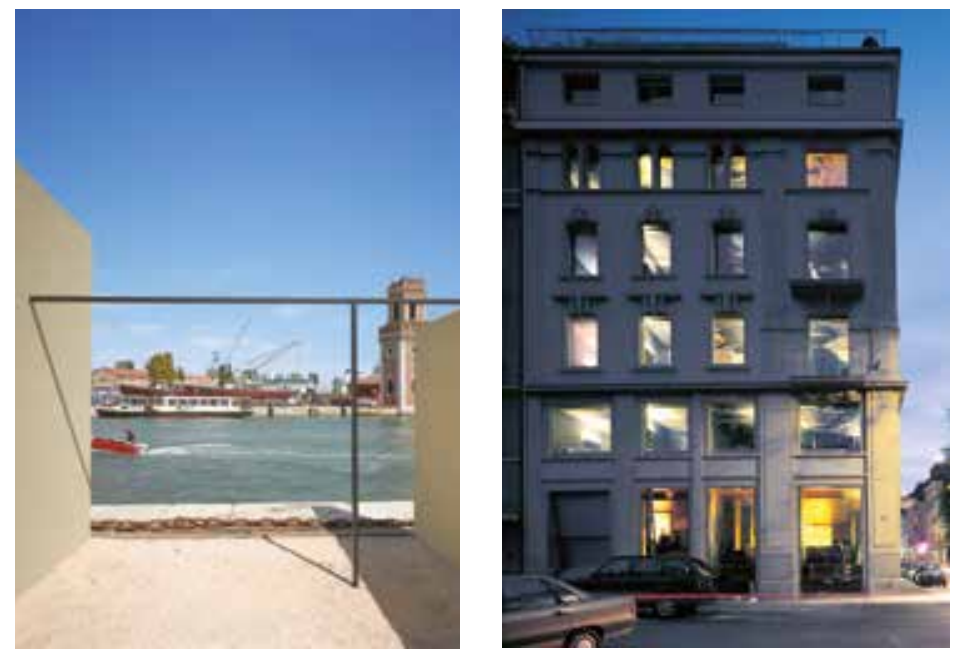

Fig. 6. Halbe, Roland: Windows, Eduardo Souto de Moura. Venecia. 2012.

Fig.7. Ruault, Philippe: The Hotel, Jean Nouvel. Lucerna. 2000. En revista El Croquis, números 112-113, p.138.

Asimilar así la arquitectura, como una de las artes en el contexto de un mundo tecnológico, también supone toda una reivindicación. Se reivindica que la arquitectura, aparte de resolver -y hacerlo bien- las necesidades objetivas que la originan, debe responder de su función en cuanto obra de arte (aún cuando su posición no sea fuerte, sino débil frente a la tecnología). En su doble naturaleza de 'arte con razón de necesidad' (17) debe responder como utensilio técnico a la necesidad, pero como objeto artístico al arte. (18) Y esta función no tiene que ver con obtener un determinado resultado estético, ni mucho menos un estilo. Cuando en la arquitectura esa oscilación -ideal y material- se centra en la estabilidad, el resultado es una levedad de carácter diferente.

Desde lo profundo del hombre, desde lo simbólico, Juan Eduardo Cirlot vinculaba la conciencia interna de ligereza con la danza en cuanto impulso de evasión, de escapar del suelo y por tanto, de la gravedad. Y la caracteriza-

Understanding architecture in this way, like one of the arts in the context of a technologic world, opens up a vindication: architecture, besides solving in an appropriate way its objective needs, also has to respond correctly to its function as a work of art (even when its position against technology is not strong but weak). In its double nature of 'art with a reason of necessity', (17) architecture has to react to necessity as a technical tool, but to art as a piece of art. (18) And this last purpose has nothing to do with obtaining a particular esthetic result, and it is far from being a style. When that oscillation -ideal and material- focuses on stability in architecture, the consequence is another kind of lightness.

From the depth of human being, from the symbolic world, Cirlot connected the inner consciousness of lightness with dance in terms of escaping impulse, escaping from ground and then from gravity. And he defined that inner consciousness of lightness by the presence of what is sonorous, mobile or transparent. (19) Referred to the human body through dance, each one of these qualities -that suggest new aspects related to lightness- become also new ways to question stability. Therefore, the field of lightness is not already reduced to the opposition between lightweight and heaviness -in a stable correspondence between matter and gravity that could be attributed to a classical point of view- but it acquires other nuances related to vision, balance or movement of a body that becomes intermediary of the experience when facing the work.

Lightness of Vision: the Case of Two Windows. To summarize these ideas, it can be useful to show two different ways to approach an apparently simple work as designing a window. In 2012 Venice Biennale, Eduardo Souto de Moura was asked 
ba por la presencia de lo sonoro, lo móvil y lo transparente. (19) Referidas al cuerpo por medio de la danza, cada una de estas cualidades -que sugieren nuevos aspectos vinculados a la levedad- se convierten también en nuevas vías para cuestionar lo estable. El campo de la levedad, por tanto, ya no se reduce a la oposición entre lo ligero y lo pesado -en una correspondencia estable entre materia y gravedad, como podría atribuirse a una interpretación clásica- sino que adquiere otros matices relacionados con la vista, el equilibrio o el movimiento de un cuerpo que se convierte en intermediario de la experiencia ante la obra.

Levedad de la visión: el caso de dos ventanas. Mostrar dos formas de acometer un ejercicio aparentemente sencillo, como proyectar una ventana puede ser útil para sintetizar estas ideas. En la Bienal de Venecia de 2012, Eduardo Souto de Moura fue el encargado de realizar un pabellón en el jardín, al norte del Arsenale, a la salida a la Laguna. La idea que desarrolló en su proyecto, Windows, fue la de mirar de tres formas diferentes a la ciudad de Venecia. Una correspondía a la arquitectura masiva, medieval o clásica, que se soportaba sobre espesos muros de carga, en los que las ventanas que se podían abrir eran estrechas y altas, abocinadas, focalizando la visión. (Fig.4) Otra correspondía a la primera arquitectura moderna, en la que se separaba el cerramiento de la estructura, los muros tenían un espesor estricto y como no tenían función portante, los huecos se podían hacer más anchos. (Fig.5)

La última de las formas corresponde a la arquitectura moderna del vidrio, en la que el marco de visión lo crea simplemente la estructura. (Fig.6) Souto de Moura, por tanto, desmaterializa el contorno de la ventana de una manera literal, física, pasando de una vista enmarcada en la potencia de un muro a una vista subrayada por unos elementos ligeros. Frente a este ejercicio de desmaterialización 'clásica' de la ventana, en el que el resultado se presenta como una secuencia según se pasea el jardín, Jean Nouvel realiza en Lucerna el diseño de The Hotel, un hotel-boutique de lujo que ocupa un edificio en esquina en el casco histórico de la ciudad. (Fig.7)

to design a pavilion in a garden at the north of Arsenale, at the exit of Venice lagoon. The idea for his project Windows was to look at Venice city in three different ways. One of these corresponded to massive architecture, medieval or classic, that rises over thick walls, where the windows that could be opened were splayed, narrow and high, focusing vision. (Fig. 4) Another way corresponded to first modern architecture, in which enclosure was separated from structure. The walls had a strict thickness and, as they did not have structural function, holes on them could be wider. (Fig. 5)

The last way corresponds to glass modern architecture, in which vision frame is made only by structure. (Fig. 6) Thus, Souto de Moura dematerializes the window's outline in a literal, physical way, moving from a sight defined by wall thickness to a sight underlined by light elements. Contrasting with this 'classic' way to dematerialize a window, in which those three stages are shown like a sequence to whom walks through the garden, Jean Nouvel designs The Hotel in Lucerne. A luxury boutique hotel located in a corner building at the historic city centre. (Fig. 7)

It is a building with very thick walls, whose windows shape its urban image in the consolidated scene of the old town. The impossibility to change its frames particularly concerns common areas, at the entrance level and the basement, because each window should be shared by both floors. Besides, these storeys accommodate two exclusive and important activities for the hotel: The Lounge (urban bar) and Bam Bou Restaurant (fusion cuisine), respectively. So, the window designed by Nouvel does not physically modify its frame but changes the perception of it and of the space where it is located, transforming the stay at both, bar and restaurant into an intense experience. (Fig. 8) And Nouvel makes this simply by using 
Se trata de un edificio con muros de carga de gran espesor, cuyos huecos conforman la imagen urbana en un entorno consolidado. No poder modificarlos afecta especialmente a las zonas comunes, en la planta baja y semisótano, puesto que cada hueco será compartido por ambos niveles. Además en ellos se ubican dos usos exclusivos e importantes para el hotel: The Lounge (urban bar) y Restaurant Bam Bou (fusion cuisine), respectivamente. La ventana que proyecta Nouvel, por tanto, no modifica físicamente el contorno del hueco, pero sí altera la percepción que se tiene del mismo y del espacio, convirtiendo tanto la estancia en el bar como en el restaurante en una experiencia intensa. (Fig. 8) Y esto lo realiza simplemente con el uso de tres vidrios inclinados en planta baja, uno de los cuales (el paralelo a fachada) desciende más allá del falso techo de la planta inferior, mientras que otros dos vidrios encastrados en el hueco de la ventana en planta semisótano y con diferente inclinación, recogen reflejos e iluminación del primer vidrio descolgado, el entorno y el resto de huecos cercanos.

Los materiales empleados, vidrio y acero, tienen en sí cualidades propias asociadas a la ligereza y la transparencia, pero es la relación entre ellos y su conjunción en un lugar y de una forma determinada lo que provoca la distorsión de la realidad de la ventana. El espaciamiento que presentan no es una distancia que se atraviese sólo físicamente, sino conceptualmente. Nouvel desmaterializa la propia función de la ventana, que es conectar un espacio interior con uno exterior, poniendo en cuestión la luz, el reflejo y la visión. Así, no anula la visión sino que la distorsiona. Ésta es fragmentaria y no directa, y con ello, lo que se hace presente es la inestabilidad, la levedad, ese desasosiego que hace replantearse certidumbres como la de pensar una sencilla ventana.

Conclusión, levedad contemporánea. Este acercamiento en tres actos, o en tres movimientos de diferente naturaleza, ha permitido comprender el enunciado inicial propuesto sobre la levedad como algo intenso, propio y característico de la arquitectura contemporánea. Una levedad debilitada que, más allá de la oposición entre categorías como ligero y pesado, encuentra su campo de actuación en el cuestionamiento de lo estable desde otros parámetros como la visión, involucrando al espectador en un diálogo que pone en duda sus certezas.

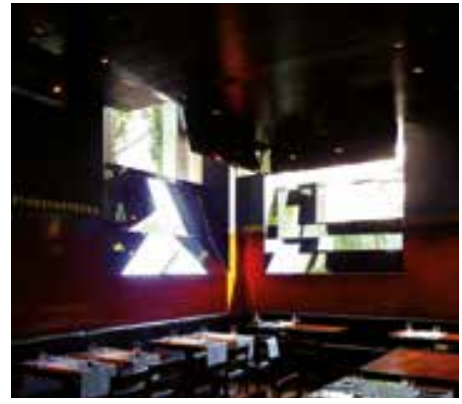

Fig. 8. Moreno, Álvaro: The Hotel, Jean Nouvel. Lucerna. 2012.

three inclined glasses in the ground floor. One of them -parallel to the façade- goes down further than the basement ceiling, while the two others -recessed in the window aperture at the basement level and with different inclination- collect reflections from light and images coming from the first glass, close environment and other near windows.

The materials used, glass and steel, have in themselves qualities associated to lightness and transparency, but it is the relationship between them, its combination in a place and in a particular way, that causes the distortion of the reality of the window. Nouvel dematerializes the function of the window itself, that is to connect inner and outer space, reconsidering light, reflects and vision. This kind of window does not cancel the vision but distorts it. This vision is fragmentary and not direct and by this what appears is the instability, the lightness, that feeling of unease that makes us reconsider convictions, such as that of designing a simple window.

Conclusion, Contemporary Lightness. This approach in three acts, or in three movements of different nature, has allowed us to understand the initial thesis proposed about lightness as somehow intense, specific and characteristic of contemporary architecture. A weakened lightness that, beyond the opposition between categories as lightweight and heaviness, finds its own field of action by reconsidering stability from other parameters as vision, involving the viewer in a dialogue that calls his convictions into question. 


\section{NOTAS}

1. CALVINO, Italo. Seis propuestas para el próximo milenio. $7^{\mathrm{a}}$. Madrid: Siruela, 2007. Primera edición en español (Siruela), 1989. Este libro de Italo Calvino se convirtió en referencia importante para los arquitectos desde su publicación en 1989. La cercanía de los conceptos tratados en sus propuestas respecto a los intereses creativos del proyecto en arquitectura las hacen enormemente sugerentes. La primera propuesta, levedad, está implícita en el planteamiento de este artículo y también es referencia en los eventos que aquí se nombran (ANY, Culture of Glass, Light Construction). Analizar su influencia sería tarea de otro artículo, pero aquí se destaca su valor e importancia como introducción del texto, para que un lector interesado pueda consultarla.

2. En alguna medida estos tres eventos se retroalimentan. Todos se desarrollan en la costa este de los Estados Unidos, en la ciudad de Nueva York y sus directores pertenecen al mismo ámbito cultural y se conocen: Peter Eisenman, Cynthia Davidson (ANY), Joan Ockman (Columbia University) y Terence Riley (MoMA). Por otra parte, revisan aspectos complementarios del tema: ANY estudia la levedad como concepto; Ockman, a través del vidrio como material de la modernidad y Riley de una forma más disciplinar, por medio de obras y proyectos.

3. No sólo como referente histórico en el arte moderno sino por su influencia global, Light Construction se exhibió posteriormente en el MACBA de Barcelona (28 junio - 13 octubre de 1996) coincidiendo con el Congreso Internacional de Arquitectura celebrado por la UIA (03-06 julio de 1996).

4. El artículo, con el mismo título que la exposición, se puede consultar en versión inglesa en el catálogo original del MoMA (RILEY, Terence y LOWRY, Gleen D. Light Construction. Nueva York : The Museum of Modern Art, 1995.) o en su versión en castellano en el catálogo de la exposición del MACB: RILEY, Terence y LOWRY, Gleen D. Light Construction. Transparencia y ligereza en la arquitectura de los noventa. Barcelona: Gustavo Gili, 1996.

5. ROWE, Colin; SLUTZKY, Robert. 'Transparency: Literal and Phenomenal Part 1', Perspecta 8: The Yale Architectural Journal. 1964. Se puede consultar junto a otros textos referidos en la exposición en: GANNON, Todd; KIPNIS, Jeffrey. The Light Construction Reader. Nueva York: The Monacelli Press, Inc., 2002.

6. La transparencia literal, como cualidad del material, asociada al muro cortina de los racionalistas modernos y la transparencia fenomenal, como abstracta o relacional, mejor explicada desde la pintura cubista.

\section{REFERENCIAS}

CALVINO, Italo. Seis propuestas para el próximo milenio. Madrid: Siruela, 2007. Primera edición en español (Siruela), 1989.

RILEY, Terence; LOWRY, Gleen D. Light Construction.Transparencia y ligereza en la arquitectura de los noventa. Barcelona: Gustavo Gili, 1996. ROWE, Colin; SLUTZKY, Robert. 'Transparency: Literal and Phenomenal, Part 1. Perspecta 8: The Yale Architectural Journal. 1964.

GANNON, Todd; KIPNIS, Jeffrey. The Light Construction Reader. Nueva York: The Monacelli Press, Inc., 2002.

KEPES, Gyorgy. Language of Vision. Painting, Photography, AdvertisingDesign. Chicago: Paul Theobald and Company, 1969.

PAZ, Octavio. Apariencia Desnuda; La Obra de Marcel Duchamp. Mexico: ERA, 1995.

VATTIMO, Gianni. El arte de la oscilación. La sociedad transparente. Barcelona: Paidós, 1990. pp. 133-154.

SOLÀ-MORALES RUBIÓ, Ignasi de. Arquitectura débil. Diferencias. Topografía de la arquitectura contemporánea. Barcelona: Gustavo Gili, 1995. pp. 63-82.

VATTIMO, Gianni. Introducción a Heidegger. Barcelona: Gedisa, 2002. ORTEGA Y GASSET, José. Meditación de la Técnica. Madrid: Revista de Occidente en Alianza Editorial, 1982.

CIRLOT, Juan Eduardo. Diccionario de símbolos. Barcelona: Labor, 1992.
7. ROWE, Colin; SLUTZKY, Robert. 'Transparency: Literal and Phenomenal', Perspecta 8: The Yale Architectural Journal. 1964. Pienso que clasificar la 'obstrucción' de forma análoga a como Rowe y Slutzky hacían con la transparencia en su artículo en Perspecta es útil para intentar comprender una idea que ofrece matices diferentes a los expuestos por Terence Riley en Light Construction.

8. RILEY, Terence y LOWRY, Gleen D. Light Construction. Transparencia y ligereza en la arquitectura de los noventa. Barcelona: Gustavo Gili, 1996. pp. 9-10. Esta idea de 'habitación de luz sin sombras', de Ludwing Hilberseimer, aparece citada por Riley en su artículo.

9. RILEY, Terence; LOWRY, Gleen D. Light Construction. Transparencia y ligereza en la arquitectura de los noventa. Barcelona: Gustavo Gili, 1996. p. 12.

10. KEPES, György. Language of Vision. Painting, Photography, Advertising-Design. Chicago: Paul Theobald and Company, 1969. p. 80. Esta apreciación no se recoge en el artículo 'Transparency: Literal and Phenomenal', de Rowe y Slutzky.

11. Extraña que no hubiera elegido obras expuestas más significativas como la Fundación Cartier.

12. PAZ, Octavio. Apariencia Desnuda; La Obra de Marcel Duchamp. México: ERA, 1995.

13. VATTIMO, Gianni. El arte de la oscilación. La sociedad transparente. Barcelona: Paidós, 1990, pp. 133-154.

14. SOLÀ-MORALES RUBIÓ, Ignasi de. Arquitectura débil. Diferencias. Topografía de la arquitectura contemporánea. Barcelona : Gustavo Gili, 1995, pp. 63-82.

15. VATTIMO, Gianni. Introducción a Heidegger. Barcelona : Gedisa, 2002. p. 108.

16. La red de significados que cada uno establece para transitar por lo que conoce y lo que aún no conoce.

17. La definición de arquitectura como 'arte con razón de necesidad', se debe a Javier Carvajal Ferrer, que siempre la utilizaba en sus clases de proyectos.

18. Según la diferenciación entre utensilio y obra de arte que establecía Ortega y Gasset. ORTEGA Y GASSET, José. Meditación de la Técnica. Madrid: Revista de Occidente en Alianza Editorial, 1982. p.102

19. La referencia al simbolismo proporciona una mirada complementaria a la de la disciplina arquitectónica. CIRLOT, Juan Eduardo. Diccionario de símbolos. 9a edición. Barcelona: Labor, 1992.

\section{REFERENCES}

CALVINO, Italo. Seis propuestas para el próximo milenio. Madrid : Siruela, 2007. First edition in Spanish (Siruela), 1989.

RILEY, Terence y LOWRY, Gleen D. Light Construction.Transparencia y ligereza en la arquitectura de los 90. Barcelona : Gustavo Gili, 1996. ROWE, Colin y SLUTZKY, Robert. 'Transparency: Literal and Phenomenal', Part 1. Perspecta 8: The Yale Architectural Journal. 1964.

GANNON, Todd; KIPNIS, Jeffrey. The Light Construction Reader. New York: The Monacelli Press, Inc., 2002.

KEPES, Gyorgy. Language of Vision. Painting, Photography, Advertising-

Design. Chicago: Paul Theobald and Company, 1969.

PAZ, Octavio. Apariencia Desnuda; La Obra de Marcel Duchamp. México: ERA, 1995.

VATTIMO, Gianni. El arte de la oscilación. La sociedad transparente. Barcelona: Paidós, 1990, pp. 133-154.

SOLÀ-MORALES RUBIÓ, Ignasi de. Arquitectura débil. Diferencias. Topografía de la arquitectura contemporánea. Barcelona: Gustavo Gili, 1995, pp. 63-82.

VATTIMO, Gianni. Introducción a Heidegger. Barcelona: Gedisa, 2002. ORTEGA Y GASSET, José. Meditación de la Técnica. Madrid: Revista de Occidente in Alianza Editorial, 1982.

CIRLOT, Juan Eduardo. Diccionario de símbolos. Barcelona : Labor, 1992. 
NOTES

1. CALVINO, Italo. Seis propuestas para el próximo milenio. Madrid: Siruela, 2007. First edition in Spanish (Siruela), 1989. This book by Italo Calvino becomes a landmark for architects since its publication in 1989. The proximity of the concepts covered in his proposals regarding creative interest in architectural design makes Calvino's proposals hugely suggesting. First of this memos, lightness, is involved in the outline of this paper and it is also a reference for the events mentioned in the article (ANY, Culture of Glass, Light Construction). Analyzing its influence would be the goal of another article, but its value and significance should be highlighted for an interested reader to consult it.

2. In some way, these three events feedback each other. All of them take place on the East Coast, in New York City, their directors belong to the same cultural field and they have met before-Peter Eisenman, Cynthia Davidson (ANY), Joan Ockman (Columbia University) and Terence Riley (MoMA). Moreover, these events go over complementary aspects of the issue: ANY studies lightness as a concept; Ockman does the same but focusing on glass as material of modernity and Riley, more disciplinary, studies lightness by means of works and projects.

3. Not only as a historic benchmark for modern art but also for its global influence: Light Construction was exhibited later at Barcelona's MACBA (28 Jun. - 13 Oct. 1996) coinciding with the Architectural International Congress that IAU held there (03-06 Jul.1996).

4. The article, entitled as the exhibition, can be found in English version in MoMA's original catalogue: RILEY, Terence; LOWRY, Gleen D. Light Construction. New York: The Museum of Modern Art, 1995 or in Spanish, in MACBA's exhibition catalogue: RILEY, Terence y LOWRY, Gleen D.

Light Construction. Transparencia y ligereza en la arquitectura de los 90. Barcelona : Gustavo Gili, 1996.

5. ROWE, Colin y SLUTZKY, Robert. 'Transparency: Literal and Phenomenal' Part 1, Perspecta 8: The Yale Architectural Journal. 1964. It can be found together with other texts related to exhibition in: GANNON, Todd; KIPNIS, Jeffrey. The Light Construction Reader. New York: The Monacelli Press, Inc., 2002.

6. Literal transparency, as the material quality associated to the curtain wall of modern rationalists, and phenomenal transparency, as abstract or relational, better explained from Cubism in painting.

7. ROWE, Colin; SLUTZKY, Robert. 'Transparency: Literal and Phenomenal' Part 1, Perspecta 8: The Yale Architectural Journal. 1964. In my opinion, it is useful to classify 'obstruction' in a similar manner as Rowe and Slutzky did regarding transparency in their article for Perspecta. This allows me to show a different idea from that exposed by Terence Riley in Light Construction.

8. RILEY, Terence; LOWRY, Gleen D. Light Construction. Transparencia y ligereza en la arquitectura de los 90. Barcelona: Gustavo Gili, 1996. pp. 9-10. The idea of 'shadowless light room', by Ludwing Hilberseimer, is mentioned by Riley in his article.

9. RILEY, Terence; LOWRY, Gleen D. Light Construction. Transparencia y ligereza en la arquitectura de los 90. Barcelona : Gustavo Gili, 1996. p. 12.

10. KEPES, György. Language of Vision. Painting, Photography, Advertising-Design. Chicago : Paul Theobald and Company, 1969. p. 80. This idea is not mentioned in the article Transparency: literal and phenomenal, by Rowe and Slutzky.

11. It is surprising that the curator has not chosen more important buildings in the exhibition to justify his point of view, like Cartier Foundation.

12. PAZ, Octavio. Apariencia Desnuda; La Obra de Marcel Duchamp. Mexico: ERA, 1995.

13. VATTIMO, Gianni. El arte de la oscilación. La sociedad transparente. Barcelona: Paidós, 1990, pp. 133-154. An English version can be found in GANNON, Todd; KIPNIS, Jeffrey. The Light Construction Reader. New York: The Monacelli Press, Inc., 2002. pp. 257-264.

14. SOLÀ-MORALES RUBIÓ, Ignasi de. Arquitectura débil. Diferencias. Topografía de la arquitectura contemporánea. Barcelona : Gustavo Gili, 1995, pp. 63-82.

15. VATTIMO, Gianni. Introducción a Heidegger. Barcelona: Gedisa, 2002. p. 108.

16. The network of meanings that everyone sets for go through the known and the still unknown.

17. In words of Javier Carvajal Ferrer, who always uses this definition during his lectures at University, architecture is an "art with a reason of necessity".

18. Following the distinction between tool and work of art by Ortega y Gasset. ORTEGA Y GASSET, José. Meditación de la Técnica. Madrid: Revista de Occidente en Alianza Editorial, 1982. p. 102

19. Symbolism provides an additional point of view to architectonic discipline. CIRLOT, Juan Eduardo. Diccionario de símbolos. Barcelona: Labor, 1992.
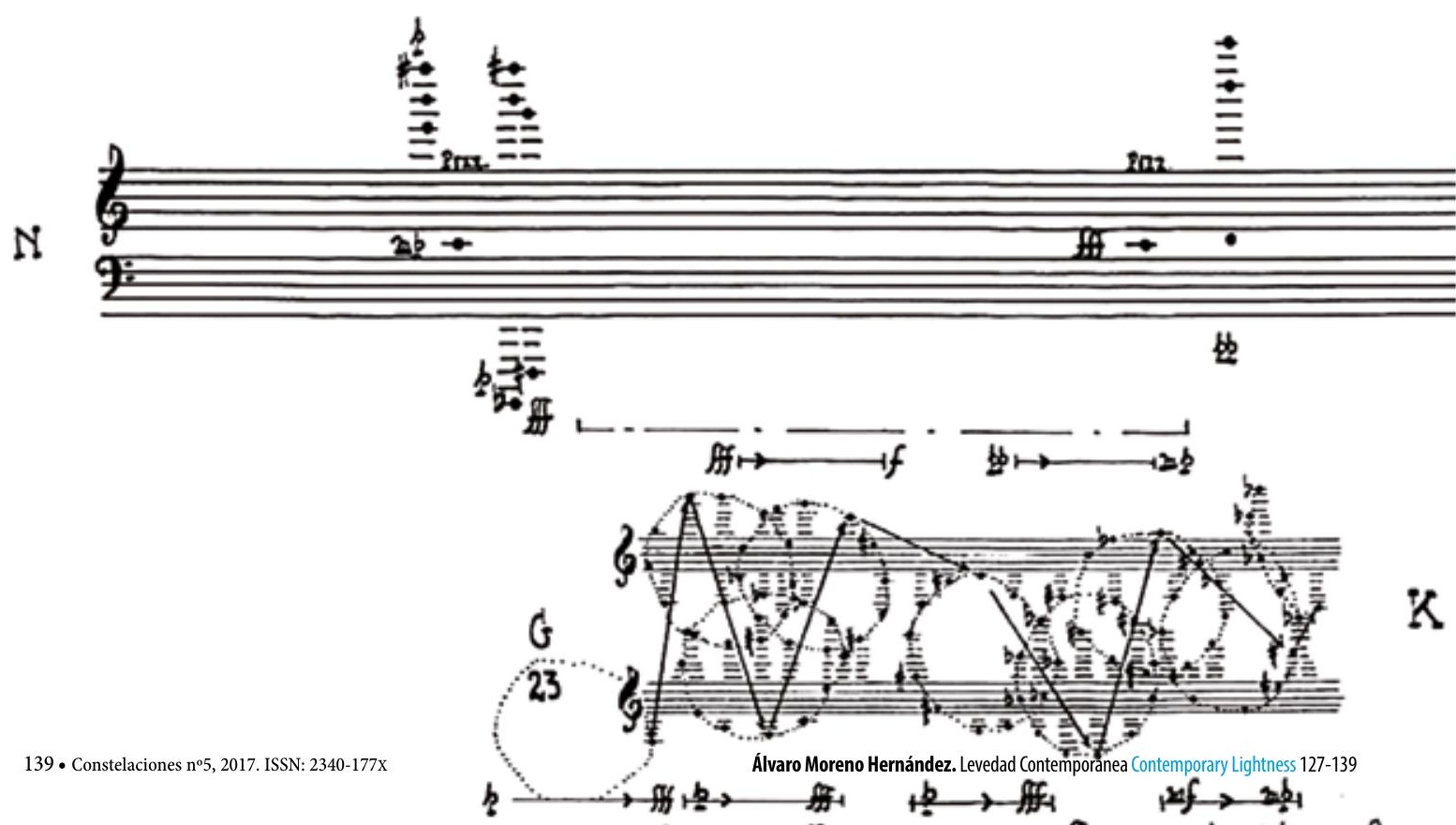